\title{
Effects of bioactive extracellular compounds and paralytic shellfish toxins produced by Alexandrium minutum on growth and behaviour of juvenile great scallops Pecten maximus
}

\author{
Borcier Elodie ${ }^{1,{ }^{*}}$, Morvezen Romain ${ }^{2}$, Boudry Pierre ${ }^{1}$, Miner Philippe ${ }^{1}$, Charrier Grégory ${ }^{2}$, \\ Laroche Jean ${ }^{2}$, Hegaret Helene ${ }^{2}$
}

${ }^{1}$ Ifremer, LEMAR, UMR 6539 (UBO-CNRS-IRD-Ifremer), Centre de Bretagne, CS 10070, 29280

Plouzané, France

${ }^{2}$ LEMAR, UMR 6539 (UBO-CNRS-IRD-Ifremer), Institut Universitaire Européen de la Mer, Technopôle Brest Iroise, Plouzané, France

* Corresponding author : Elodie Borcier, email address : elodie.borcier@gmail.com

\begin{abstract}
:
Dinoflagellates of the genus Alexandrium are a major cause of harmful algal blooms (HABs) that have increasingly disrupted coastal ecosystems for the last several decades. Microalgae from the genus Alexandrium are known to produce paralytic shellfish toxins (PST) but also bioactive extracellular compounds (BEC) that can display cytotoxic, allelopathic, ichtyotoxic or haemolytic effects upon marine organisms. The objective of this experimental study was to assess the effects of PST and BEC produced by $A$. minutum upon juvenile great scallops Pecten maximus. Scallops were exposed for one week to two different strains of $A$. minutum, the first producing both PST and BEC and the second producing only BEC. Escape response to starfish, daily shell growth, histological effects, and accumulation of PST were recorded after one week of exposure, and after two subsequent weeks of recovery. Daily shell growth was delayed three days in scallops exposed to the BEC-producing $A$. minutum strain, probably during the three first days of exposure. An increase of reaction time to predators was observed in scallops exposed to the BEC condition, suggesting that BEC may have altered sensing processes. Scallops exposed to PST displayed a less-efficient escape response and muscular damage which could reflect the effects of paralytic toxins upon the nervous system of scallops. This study demonstrates contrasting effects of the distinct toxic compounds produced by $A$. minutum upon marine bivalves, thus highlighting the importance to better characterize these extracellular, bioactive compounds to better understand responses of other marine
\end{abstract}




\section{Highlights}

- Alexandrium sp. can produce paralytic shellfish toxins and other bioactive extracellular compounds with allelopathic and cytotoxic activity. Extracellular bioactive compounds cause tissue alteration, thus altering recognition and feeding processes of $P$. maximus. Paralytic shellfish toxins reduce the efficiency of scallop $P$. maximus escape response and cause muscular damages. It is important to characterize the different compounds and their effects, when assessing the impact of Alexandrium on marine organisms

Keywords: Harmful Algal Bloom (HAB), Alexandrium minutum, Pecten maximus, Paralytic Shellfish Toxins (PST), extracellular compounds, behaviour, histology 


\section{Introduction}

Harmful Algal Blooms (HABs) develop mainly near coastal waters (Sellner et al., 2003) and have been reported worldwide (Van Egmond et al., 1993; Bricelj \& Shumway, 1998; Sellner et al., 2003; Lassus et al., 2006). Dinoflagellates of the genus Alexandrium Halim (1960) are among the most prominent HABs in terms of intensity, diversity, and distribution worldwide (Anderson et al., 2012). Species of Alexandrium, such as A. minutum or A. catenella, are known to produce neurotoxins, which include saxitoxin (STX) and its derivatives (21 congeners), also known as paralytic shellfish toxins (PST). STX blocks the passage of sodium ions in nerve cell sodium channels, leading to severe neuromuscular disorders, especially among consumers of intoxicated flesh (Château-Degat, 2003). Thus, PSTs present a very acute toxicity for aquatic organisms (Landsberg, 2002) and human consumers (Lassus et al., 2006; Anderson et al., 2012). PSTs are responsible for the "Paralytic Shellfish Poisoning" (PSP) syndrome that can modify the trophic structure of marine food webs, by causing intoxication or death of many organisms (Anderson et al., 2012). Species of Alexandrium are also known to produce others toxic molecules, independently from PST (Tillman and John, 2002), which are excreted extracellularly and can have deleterious effects upon organisms when excreted into surrounding seawater. These compounds can have cytotoxic (Arzul et al., 1999, Ford et al., 2008, Tillmann et al., 2008) allelopathic (Lelong et al., 2011), haemolytic (Arzul et al. 1999), or growth inhibition impacts on marine organisms, such as neighbouring phytoplanctonic cells, molluscs, or, fishes (Tang et al., 2007, Landsberg, 2002 Haberkorn et al., 2010a,b; Lambert et al., 2013). Extracellular bioactive compounds associated with Alexandrium cytotoxicity still remain unidentified chemically. Emura et al. (2004) first identified from A. taylori protein-like, hemolytic compounds with molecular weights larger than 10,000 Da. Later, Flores et al. (2012) also found evidence for protein-like compounds with cytotoxic activity to heterotrophic protists from A. tamarense cultures; in this study, toxicity was also linked to Reactive Oxygen Species (ROS). Conversely, Yamasaki et al. (2008) were not able to detect a candidate protein, but suggested the possibility that a polysaccharide-based compound produced by $A$. tamarense could be responsible for effects observed. Meanwhile Ma et al. (2009) isolated from A. tamarense a large, amphiphathic compound with lytic activity. The nature of the compounds inducing cytotoxic activity is 
therefore clearly far from being elucidated. The use of a phytoplankton bioassay in this study thus allows detection and semi-quantification of cytotoxic compounds in solution.

The great scallop P. maximus is a marine bivalve that lives in coastal waters at the surface of, or slightly buried in, the sediment (Baird, 1958). This scallop appears to have three responses to disturbance that are mostly chemosensory (Thomas \& Gruffydd, 1971; Brand, 2006): closing valves, jumping, and vigorous swimming. Great scallops are exposed to HABs in their habitat (Shumway et al., 1990; Chauvaud et al., 1998; Chauvaud et al., 2001; Lorrain et al., 2000). Despite the important commercial value of $P$. maximus, information is scarce regarding the response of this organism to toxic phytoplankton blooms and the potential for these scallops to accumulate toxins. In mussels and oysters, numerous studies have assessed exposure to A. minutum and toxin accumulation, filtration and feeding activities, valve activity, as well as other physiological variables, such as immune response, antioxidant response, tissue damages, or reproduction (Bougrier et al., 2003; Fabioux et al., 2015; Haberkorn et al., 2010a,b, 2011; Tran et al., 2010, 2015). A recent study demonstrated a modified escape response of the Peruvian scallop Argopecten purpuratus Lamarck (1819) to the predatory starfish Meyenaster gelatinosus Meyen (1834), when exposed to A. catenella (Whedon \& Kofoid) Balech (1985) (Hégaret et al., 2012). The escape response of scallops appears as a biologically relevant physiological indicator as it represents a consistent response (Ortiz et al., 2003), consisting of altered adduction/abduction movements propulsing the individual by expulsing water from the dorsal side (Brokordt et al., 2006). Further, escape response is relatively simple to measure to evaluate the status of scallops (Guderley et al., 2011).

Previous studies have highlighted alteration of the growth of P. maximus in the Bay of Brest, in relation to the effects of microalgal extracellular compounds. For instance, a lack of growth has been reported in P. maximus following a bloom of the toxic dinoflagellate Gymnodinium cf. nagasakiense Takayama \& Adachi (1985) (= actual Karenia mikimotoi (Miyaka \& Kominami ex Oda) Hansen \& Moeastrup (2000)) (Chauvaud et al. 2001). Moreover, growth alteration and inhibition, as well as mortality, have been observed in great scallop juveniles in response to a Karenia mikimotoi bloom (Chauvaud et al., 2001; Erard-Le-Denn et al., 1990; Le Floc'h et al., 2008). This algal species produces several extracellular compounds with putative cytotoxic (allelopathic and haemolytic) activities (Gentien \& Arzul, 1990; Arzul et al., 1999; Gentien, 2006; Gentien et al., 2007), which are suspected to be responsible for the altered growth patterns observed in scallops. 
The present study was undertaken to experimentally assess, under controlled conditions, the possible effects of PSTs and extracellular compounds produced by A. minutum upon growth, escape, and histological responses of juvenile P. maximus. Individuals were exposed to two strains of A. minutum, one producing both PSTs and bioactive extracellular compounds (BEC), and the other producing only BEC, to discriminate possible different effects of these toxins on the physiological responses of juvenile scallops.

\section{Materials and methods}

\section{Biological material}

Juvenile Pecten maximus (7-8 gr; $38-40 \mathrm{~mm}$ ) were obtained from the Tinduff hatchery (Plougastel-Daoulas, France) and acclimatized to experimental conditions for 45 days before the start of the experiment. In parallel, starfish Asterias rubens were sampled in the Bay of Brest by scuba diving three days before the "escape response assays" and maintained in a 120 -L tank with running seawater $\left(14^{\circ} \mathrm{C}\right)$.

Algal cultures of Tisochrysis lutea (clone T-iso) Bendif et al. (2013) and Chaetoceros neogracile VanLandingham (1968) (=C. muelleri, Strain CCAP1010/3), two species commonly used as feed in bivalve hatcheries, were produced as the principal diet. T-iso was first cultivated in continuous culture and $C$. neogracile in batch culture, with Conway medium (Walne, 1970) in 1- $\mu \mathrm{m}$-filtered, UV-sterilised seawater. These strains were cultured in 10-L bottles before being inoculated into 150 - $\mathrm{L}$ cylinders maintained at $18^{\circ} \mathrm{C}$. To optimize growth conditions, cylinders were aerated with a mix of air and $\mathrm{CO}_{2}$ and the cellular density of the mixture (T-iso $+C$. neogracile) was in the range of $2.04 \times 10^{7}$ cells per day per scallop \pm 2.71 $\mathrm{x} 10^{5}$ cells per day per scallop.

Two strains of A. minutum were used in the study. The first, AM89BM, hereafter referred to as "PST" for convenience, was isolated from a bloom in the Bay of Morlaix, Brittany, France (Erard-Le-Denn et al., 1990). This strain is known for high PST content (Haberkorn et al. 2010a,b), but produces also bioactive extracellular compounds (BEC) (Lelong et al., 2011). The second strain, CCMI1002, hereafter named "BEC", was isolated from a bloom in Ireland (Tillmann \& John, 2002). No PST production has been detected in this strain, but it produces a large amount of BEC (more than the AM89BM strain), with known allelopathic and cytotoxic activity (Lambert et al. 2013). Both A. minutum strains were grown with L1 medium made with autoclaved, 1- $\mu \mathrm{m}$-filtered seawater (Guillard \& Hargraves, 1993). Alexandrium strains were cultured in 2-, 6-, and 10-L glass bottles before being inoculated into $300-\mathrm{L}$ cylinders and incubated at $15^{\circ} \mathrm{C}$ with a $12 \mathrm{~h} / 12 \mathrm{~h}$ photoperiod. Aeration, without 
$\mathrm{CO}_{2}$ supplement, was maintained in the cylinders, and $\mathrm{pH}$ was constantly checked to supply favourable conditions for growth. Cultures were grown without antibiotics and were not free of bacteria.

For the preliminary experiment, cultures of $C$. neogracile were grown with F/2-medium with Si made with autoclaved, 1- $\mu$ m-filtered seawater (Guillard and Ryther 1962, Guillard 1975) at $18^{\circ} \mathrm{C}$ with a $12 \mathrm{~h} / 12 \mathrm{~h}$ photoperiod.

\section{Preliminary experiment: cytotoxicity assay}

To assess the cytotoxicity of both A. minutum strains, the production of cytotoxic, allelopathic compounds by the two A. minutum strains was tested on $C$. neogracile according to the protocol developed by Lelong et al. (2011), which was used as a bioassay. When A. minutum cultures reached the end of the exponential growth phase, they were centrifuged and resuspended in clean, new medium in triplicate at $10^{4}$ cell $\mathrm{mL}^{-1}$. Analyses of allelopathic effects were performed $24 \mathrm{~h}$ after inoculating cultures to standardize the time allowed for production of allelopathic compounds. Before each sampling, cultures were mixed by gentle, manual shaking.

Supernatants from A. minutum cultures was separated by centrifugation $(10 \mathrm{~min}, 800 \times \mathrm{g}$, $18^{\circ} \mathrm{C}$ ) and filtered to $0.2 \mu \mathrm{m}$ (acetate cellulose filters, Minisart, Sartorius, Göttingen, Germany). The supernatant was prepared just before the experiment and added to $C$. neogracile cultures directly after filtration. For each condition, $2 \mathrm{~mL}$ of the supernatant was added to $3 \mathrm{~mL}$ of $C$. neogracile culture, with a final cell density of $10^{5}$ cell $\mathrm{mL}^{-1}$ of $C$. neogracile in exponential growth phase. Un-inoculated F/2 medium was used as a control, as performed in Lelong et al. (2011).

Bioassays were performed in triplicate in $15-\mathrm{ml}$, pre-sterilized falcon tubes maintained in culture conditions for 3.5 hours prior to analyses, which consisted in measuring the quantum yield and the chlorophyll fluorescence of $C$. neogracile, which were the first variables affected in the experiment by Lelong et al. (2011) prior to cell mortality

Quantum Yield (QY), a measure of the efficiency of photosynthesis, was measured using a PAM AquaPen-C AP-C 100 fluorometer (Photo Systems Instruments, Czech Republic), on cells of $C$. neogracile after $20 \mathrm{~min}$ of dark adaptation at $16^{\circ} \mathrm{C}$ according to the formula:

$$
\mathrm{QY}=\mathrm{Fv} / \mathrm{Fm}=(\mathrm{Fm}-\mathrm{F} 0) / \mathrm{Fm},
$$

where F0 and Fm are the minimum and maximum fluorescence of cells at $455 \mathrm{~nm}$, respectively. 
Chlorophyll fluorescence was assessed using a FACSCalibur (Becton Dickinson) flow cytometer, with an argon blue laser $(488 \mathrm{~nm})$ and three fluorescence detectors: FL1 (green, $530 \mathrm{~nm}$ ), FL2 (orange, $585 \mathrm{~nm}$ ), FL3 (red, $670 \mathrm{~nm}$ ). Red fluorescence (FL3) is linearly correlated with the chlorophyll content of cells and was thus used to discriminate living microalgal cells in cytograms.

\section{Experimental design for the exposure experiment}

A population of 1620 scallops was distributed haphazardly into six, 120-L tanks (i.e. 270 per tank). Two replicate tanks were used per condition (see below for the conditions). Each tank was filled with three replicate trays containing 90 juvenile great scallops each. The tanks were supplied with running seawater, pumped from the bay of Brest, filtered successively to $10 \mu \mathrm{m}$ and $5 \mu \mathrm{m}$ at a continuous flow of $200 \mathrm{~mL} \mathrm{~min}^{-1}$.

Juvenile scallops were fed with a regular diet of $C$. neogracile and T-iso, which was mixed at the inlet of seawater (T-iso and C. neogracile: 50/50 dry weight (DW) per DW of scallops). During the first week of acclimation, scallops were maintained at $10.5^{\circ} \mathrm{C}$. Then, every threefour days, the temperature and photoperiod were increased respectively by $0.5^{\circ} \mathrm{C}$ and $30 \mathrm{~min}$ day light, to reach $14^{\circ} \mathrm{C}$ and 14 hours of day light after acclimation, i.e. 45 days. The protocol was intended to simulate the gradual increase of the spring photoperiod and temperature, to stimulate scallop growth (Fig. 1A).

After 45 days of acclimation, scallops were exposed for one week to either of the two $A$. minutum strains or to a control diet (as during acclimation). The supply in A. minutum in the two HAB treatments was supplemented to the regular diet in four of the tanks and inserted in parallel $\left(25 \mathrm{~mL} \mathrm{~min}^{-1}\right.$ per tank, $4.17 \mathrm{~mL} \mathrm{~min}^{-1}$ per tray at the concentration of $3 \times 10^{4}$ cell $\left.\mathrm{mL}^{-1}\right)$. Three different conditions were thus run in the experiment:

(1) A control condition, in which scallops were fed with the regular food diet only, containing of a mix diet of $T$-iso and C. neogracile, hereafter named "CON";

(2) Scallops exposed to "PST" A. minutum and

(3) Scallops exposed to "BEC" A. minutum.

The daily rations were quantified at $2.33 \times 10^{6}\left( \pm 3.45 \times 10^{4}\right)$ of $A$. minutum cells per day per scallops for the PST strain and $2.08 \times 10^{6}\left( \pm 7.14 \times 10^{4}\right)$ of A. minutum cells per day per scallop for the BEC strain. 
At the end of the seven days of exposure to the harmful algae, scallops from the three conditions were fed two extra weeks with the regular food diet to simulate a post-bloom phase.

For the purpose of the study, only 120 scallops distributed among all trays were analysed over the course of the experiment (Fig. 1A). First, 30 non-tagged scallops (10 per condition) were used to assess muscle condition index (MCI), 5 per condition were sampled after the week of exposure, and 5 per condition after the two-week recovery. Additionally, 30 scallops per condition (90 in total) were individually tagged with a RFID chip and weighed and measured once a week over the entire course of the experiment. After the seven days of exposure to the harmful algae, these 30 scallops per condition were challenged with the escape-response test, 15 per condition were sacrificed to perform histological and weight condition index (WCI) measurements, among which 10 per condition were used to measure toxin content in the digestive glands. The 45 remaining, live, tagged scallops (15 per condition) were put back in the tanks for 2 extra weeks of depuration. After the depuration phase, these 45 tagged scallops (15 per treatment) were subjected to the escape response test before being scarified to measure and to perform analyses of toxin content in the digestive glands (on 10 per condition). Shells of all these 120 scallops were collected, after exposure and after depuration, to measure shell growth (Fig. 1B).

\section{Estimation of algal cell consumption}

Algal cells (T-iso, C. neogracile, and A. minutum) from the inflow and outflow of the tanks from all conditions were monitored during the exposure phase of the experiment. Cell counts were performed using flow cytometry, as described above. The cytograms allowed us to differentiate the three algal species.

The clearance rate $(\mathrm{CR})$ was evaluated by calculating the consumption of diet algae according to the formula:

$$
\frac{C i-C o}{C o} \quad C R=F X
$$

where $\mathrm{F}$ corresponds to the flow rate in $\mathrm{L} \mathrm{h}^{-1}$,

$\mathrm{Ci}$ the cell concentration in the inflow, in cell $\mathrm{mL}^{-1}$, and Co the cell concentration in the outflow, in cell $\mathrm{mL}^{-1}$.

During the exposure phase, biodeposits were collected three times per week and observed by fluorescence microscopy to confirm algal ingestion. 


\section{Evaluation of escape response}

Each tested scallop was placed individually in a $25-\mathrm{L}$ flat, rectangular container filled with filtered seawater at $14^{\circ} \mathrm{C}$, following a protocol adapted from Brokordt et al. (2006).

The starfish A. rubens was selected as the predator, as Guderley et al., (2015) demonstrated that the predatory starfishes evoke the strongest response. The mantle of scallops was thus stimulated with an arm of the starfish. Several indicators of escape response were evaluated (adapted from Brokordt et al., 2006):

1. Reaction time (Rt): the time elapsed between the first contact of the starfish arm with the mantle edge of the scallop and the first clap.

2. Clapping time $(\mathrm{Ct})$ : duration of the clapping response.

3. Total time $(\mathrm{Tt})$ : total duration of the experiment $(=\mathrm{Rt}+\mathrm{Ct})$.

4. Number of claps $(\mathrm{Nc})$ : number of claps performed by the scallop to escape the starfish.

5. Clapping rate $(\mathrm{Cr})$ : number of claps per second $(=\mathrm{Nc} / \mathrm{Ct})$.

After exhaustion, when the scallop stopped clapping, it was allowed to recuperate for 5 minutes before being challenged a second time to test for individual repeatability.

Containers were rinsed after 2-3 scallop assays to eliminate all residues derived from interactions between the starfish and the scallops (flesh residues or molecules). Starfish were changed after 2-3 assays, but the same starfish was used for the two successive stimulations of each scallop.

At the end of the escape response challenge, scallops were dissected for histology and toxin measurements on digestive gland.

\section{Condition index}

Condition index was calculated using the wet flesh weight.

The first was the weight condition index (WCI) adapted of Fulton et al. (1911) and Ernst et al. (1991), based on the individual total weight (Twi (g)) and the shell length (L (mm)):

$$
\frac{T w i \times 10^{4}}{L^{3}} W C I=
$$

The muscular condition index (MCI) was also also assessed, following Fulton et al. (1911) and Ernst et al. (1991), based on the weight of the adductor muscle (Wam): 


\section{$\frac{W a m \times 10^{4}}{L^{3}} M C I=$}

\section{Toxin quantification}

After both exposure and recovery phases, PSTs in scallops $(\mathrm{n}=10)$ were quantified in the digestive glands of 10 individuals, which is the organ wherein accumulation is maximal (Manfrin et al., 2012). After dissection, digestive glands were preserved in liquid nitrogen before being homogenized and preserved in hydrochloric acid ( $\mathrm{HCl} 0.1 \mathrm{M})$. Samples were then centrifuged, and hydrolysed by heating at $104^{\circ} \mathrm{C}$, and PSTs were quantified using a Saxitoxin (PSP) ELISA kit (Microtiter Plate, Abraxis, Warminster, Pennsylvania, USA), following the manufacturer's protocol.

\section{Histological assessments}

Fifteen scallops per condition were examined by eye and microscopically after exposure to search for the eventual occurrence of tissue damage at the end of the exposure period. Individual scallops were prepared for histological analyses as follows: after examination for gross abnormalities, a section of soft-tissues ( $5 \mathrm{~mm}$ thick), including gills, mantle, digestive gland, and adductor muscle, was excised and fixed in Davidson's solution (Shaw and Battle, 1957) for $48 \mathrm{~h}$ at $4^{\circ} \mathrm{C}$ before being preserved in $70^{\circ}$ ethanol. Tissue sections were dehydrated in ascending ethanol solutions, then cleared with claral, and embedded in paraffin wax. Five$\mu \mathrm{m}$ thick sections were stained with Harris' hematoxylin and Eosin (Howard et al., 1983), and histopathological lesions were observed under a light microscope. Intensity of each histopathological observation was rated using a three-level, semi-quantitative scale ranging from 0 to 3 .

\section{Evaluation of shell growth}

Shell growth was assessed in all 120 scallops. Shell growth was measured 20 days after the recovery period, to readjust the curves, for all conditions. External shell growth rings were examined individually at the surface of the external face of the left valve (Clark, 1974; Chauvaud et al., 1998). Scallops (class 0+), spawned in April 2013 (class A), were brought to the laboratory in January 2014 after half a winter in the natural environment in the Bay of Brest. Shells thus included an early winter bulge, characterised by a tightening of growth 
rings (Antoine, 1978). Shell growth rate was measured from the outside to the inside (bulge) of the shell, according to a protocol adapted from Chauvaud et al. (1998) and Lorrain et al. (2002), which preconizes to read the rings along the dorsal-ventral axis only. Growth rings were counted in triplicate along three separate axes (the central axis, as well as two axes $25^{\circ}$ right or left from this central axis). To improve the reading, excessively-developed ridges of daily growth rings were removed by a $1 \mathrm{~min}$ bath in $10 \%$ acetic acid.

The distance between rings was measured under a microscope using image analysis (Visilog 7 software). The distance $\left(\mathrm{D}_{\mathrm{AB}}\right)$ between any two adjacent rings ( $\mathrm{A}$ and $\mathrm{B}$ ) was determined using the equation: $\quad D_{A B}=\sqrt{\left(x_{a}-x_{b}\right)^{2}+\left(y_{a}-y_{b}\right)^{2}}$, where $\mathrm{X}$ and $\mathrm{Y}$ are point coordinates. Pixel measurements were converted into distance $(\mu \mathrm{m})$ after calibration with known measurement unit $(0.4 \mathrm{~mm})$.

\section{Statistical analyses}

All statistical analyses were conducted with the R software v. 3.1.2. (Boston, Massachusetts, United States, 2013). An analysis of variance (ANOVA) was performed on data following a normal law (Shapiro test) and showing homogeneity of variances (Bartlett test). A Tukey post-hoc test was further performed to compare the different treatments. Data which did not follow a normal distribution and/or homogeneity were analysed using nonparametric KruskalWallis tests and compared by a multiple comparison test (Wilcoxon test).

Dependent data (same individuals, same condition, different times), were compared with an ANOVA with repeated measures (if normality and/or homogeneity of data were confirmed). If the $\mathrm{H} 1$ was rejected $(\mathrm{p}<0.05)$, a Tukey post-hoc test was used after student test. If normality or homogeneity of data were insufficient for parametric statistics, a Paired Wilcoxon test was applied with function Pairwise Wilcoxon test after false discovery rate (fdr) multiple correction.

For histopathology results, a unilateral Mann-Whitney U test $(\alpha=0.1)$ was used to assess the effects of algal treatments after the exposure phase to A. minutum. A Pearson correlation test was used to fit all growth curves between conditions, using shell growth-ring measurements. 


\section{Results}

Preliminary experiment: Bioassay of cytotoxicity of the two strains of A. minutum

Significant effects of supernatants of both A. minutum strains on $C$. neogracile on both chlorophyll pigments (FL3) and efficiency (QY) were observed (Table 1). The BEC A. minutum strain was the most allelopathic strain, significantly decreasing quantum yield and chlorophyll fluorescence of $C$. neogracile after only $3.5 \mathrm{~h}$ of incubation (Table 1). The PSP A. minutum strain also produced some extracellular bioactive compounds with allelopathic effects, but to a lesser extent than the BEC strain (Table 1).

\section{Effects of A. minutum upon scallop physiology}

Consumption of food and A. minutum during exposure

Monitoring of algal cells in the inflow and outflow of the tanks showed no significant differences in the amount of T-iso and $C$. neogracile concentrations between the treatments, and no A. minutum cells were detected in the CON condition. Microscopic observations of scallop faeces showed that intact cells of $A$. minutum had been ingested but not totally digested (Fig. 2). Again, no A. minutum cells were observed in the CON condition.

Clearance rates of scallops exposed to both A. minutum strains were significantly lower than those of individuals in the CON condition (Table 2). This decrease in clearance rate was stronger for scallops exposed to the BEC condition, even though it started to recover slightly after five days of exposure.

\section{Effects of A. minutum upon escape response}

At the end of the exposure phase, the reaction time of scallops increased significantly in the BEC condition in the second challenge, but not in the first challenge (Fig. 3.A, 3.B, Supplementary data 1). The number of claps and the clapping time were significantly lower in the PST condition for both challenges (Fig. 3.C, 3.D, 3.E, 3.F, Supplementary data 1). Moreover, the clapping time of BEC scallops was significantly higher than control and PST treatments in the second challenge (Fig. 3.F, Supplementary data 1). No significant difference in clapping rate was observed in any of the treatments regardless of the challenge (Fig. 3.G, 3.H, Supplementary data 1 ).

At the end of the exposure phase, scallops also showed a significantly faster mean reaction time in the second challenge than the first, which corresponded to the first contact with the starfish (Fig. 3.A, 3.B, Table 3) for scallops exposed to both BEC and PST. Scallops exposed to BEC also showed a significantly higher number of claps (Fig. 3.C, 3.D, Supplementary 
data 1) and clapping time (Fig. 3.E, 3.F, Supplementary data 1) in the second challenge compared to the first.

After the recovery phase, all differences observed between treatments, as well as between challenges, disappeared (Supplementary data 1).

When comparing the escape response between the exposure and the recovery phase, a few significant differences can be highlighted. After the recovery phase, a significant reduction in the reaction time was observed in the first challenge for the BEC and CON conditions (Supplementary data 1). The number of claps also significantly increased for the BEC and PST conditions in the first challenge (Supplementary data 1). The clapping rate also significantly increased for the first challenge in the BEC condition and the second challenge for the PST condition (Supplementary data 1).

\section{Condition index}

No significant differences were found for weight condition index (WCI) and muscular condition index (MCI) between conditions (CON, PST, UEM) or periods (after exposure and recovery).

Paralytic shellfish toxin (PST) accumulation in great scallops exposed to A. minutum As expected, no PSTs were detected in CON and BEC conditions. In contrast, scallops from the PST condition accumulated toxins in the digestive gland, at a concentration of $4.4( \pm 1.87)$ $\mu \mathrm{g}$ STX.g ${ }^{-1}$. This concentration appeared to begin to decrease, but not significantly (Kruskal

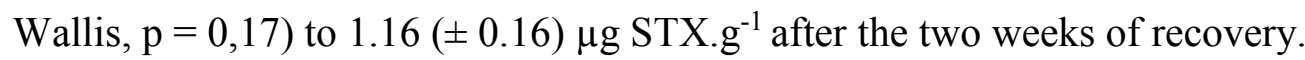

\section{Histological assessment}

Histological observations of scallops after the exposure phase showed significant effects of both A. minutum strains (Table 3). In particular, the BEC strain caused a significantly higher level of melanisation.

Despite some melanisation and haemocyte infiltration, which occurred regardless of the treatment, no significant effect was found in scallop gills (Table 3). Melanisation and haemocyte infiltrations were, however, significantly higher in the mantle of scallops exposed to both A. minutum strains (Table 3, Fig. 4A, B). Overall, the adductor muscles of scallops exposed to both BEC and PST conditions displayed higher levels of haemocyte infiltration, hyalinisation of muscle fibers, and atrophy (Table 3, Fig. 4C, D). In particular, haemocyte infiltration in the adductor muscle were significantly higher in the BEC condition. The presence of brown cells, haemocyte infiltration, and alterations were observed in digestive tubules of all scallops exposed to A. minutum, but alterations were significantly higher only in scallops exposed to the PST strain (Table 3, Fig. 4E, F). 


\section{Effect of A. minutum upon daily shell growth}

Shell growth (number and size of growth rings) appeared equivalent for PST and CON conditions (Fig. 5). In contrast, a mean difference of three daily growth rings was found for scallops exposed to the BEC condition, indicating slower growth. The Pearson correlation coefficient (r) between growth curves of BEC and other conditions was maximal with a threeday shift (Pearson correlation, $r=0.95, \mathrm{p}$-value $=6.82 \times 10^{-6}$ ). It was thus assumed that these scallops in the BEC treatment had a growth deficit during the first three days of exposure and then expressed the same growth pattern as in the other two treatments after three days (Fig. 5).

\section{Discussion}

The present study investigated the effects of two strains of A. minutum upon the physiology, growth, and behaviour of juvenile great scallops. To that end, ingestion rate, toxin accumulation, tissue alteration, growth rate, and escape response were investigated after exposure of scallops to each strain. The experiment was also designed to compare the effects of PSTs with those of BEC upon scallop physiology.

\section{Differences between the two tested A. minutum strains}

The Chaetoceros bioassay results presented here show that both strains produce extracellular bioactive compounds with allelopathic effects, but that the BEC A. minutum strain has a stronger allelopathic effect, suggesting higher production of BEC or a higher toxicity of this strain. Bioactive extracellular compounds of these two strains have already been shown to affect other cell types, such as haemocytes or spermatozoa (Lambert et al. 2013), with the similar intensity as observed in the present study. Indeed, the BEC strain was previously demonstrated to cause responses in oysters Crassostrea gigas and clams Ruditapes philippinarum, in terms of feeding behaviour (Contreras, 2011) (much more than the PST strain), presumably because of BEC. The cytotoxicity of extracellular compounds released by Alexandrium spp. cultures have clearly been shown, with damages to cell membranes inducing immobilization, cell distortion, lysis, and mortality (Tillmann et al., 2008, Tillmann et al., 2007, Tillmann \& John, 2002). Lelong et al. (2011) also clearly showed that these mechanisms are associated to damages to the photosynthetic system, which is affected very rapidly after contact with the compounds (less than $30 \mathrm{~min}$ ). Our results thus highlight in a short amount of time the cytotoxic effect of the extracellular compounds released by $A$. minutum. 


\section{Behavioral and physiological effects upon scallops resulting from exposure to BEC}

Shell Growth

A 3-day growth delay was observed in the BEC condition. Daily shell growth of scallops $P$. maximus is food-dependent (Antoine 1979; Chauvaud et al., 1998), and a growth delay observed in the wild has been attributed to exposure to the toxic algae Gymnodinium cf nagasakiense (syn. Karenia mikimotoi) (Chauvaud et al., 1998). Congruently, this algal species is known to produce bioactive, extracellular compounds (Arzul et al., 1995; Satake et $a l .$, 2002) that may have deleterious effects upon the gills and/or mantle of scallops. As a consequence, scallops may stop feeding in response to BEC, which affects shell growth. Nielsen and Strømgren (1991) have also reported a reduction in shell growth of Mytilus edulis after feeding on the toxic alga Gyrodinium aureolum (=syn. K. mikimotoi= G. nagasakiense), as well as Alexandrium ostenfeldii, Chrysochromulina polylepis, and Gymnodinium galatheanum. Exposure to these algae leads to valve closure and reduced filtration, and this may be a response to the bioactive compounds produced by most of these algal species (Smolowitz \& Shumway, 1997; Li et al., 2002; Gentien et al., 2006; Krock et al., 2006).

\section{Feeding rate}

Reduced filtration rate was observed in great scallops exposed to the BEC strain; scallops were constantly open with tentacles retracted (data not shown). This behaviour was not observed in scallops exposed to the PST strain, which still caused an intermediate, decreased filtration rate. Filtration rate of bivalves has been shown to be relatively unaffected by PSTproducing algae (Shumway \& Cucci, 1987; Gainey \& Shumway, 1988; Li et al. 2002; Wilkens, 2006), which suggests that the intermediate response to the PST condition could be induced by the BEC produced by the "PST" AM89BM A. minutum strain (as shown by the intermediate allelopathic effect).

Two hypotheses can explain this decrease in filtration rate. First, bioactive compounds excreted by both A. minutum strains may have allelopathic effects upon food cells (T-iso and C. neogracile), either affecting nutritional value or inducing the formation of undigested aggregates. As stated in the Introduction, the allelopathic and deleterious effects of Alexandrium spp. have been documented on other algal species (Arzul et al. 1999; Tillman et al. 2007; Lelong et al., 2011). Additionally, BEC could also induce the production of Transparent Exopolymeric Particles (TEPs) by food algae (Villacorte et al., 2013), causing them to form aggregates, and clogging scallop gills. Thus, BEC could affect sympatric 
microalgal taxa and indirectly affect food quality and availability for scallops. To test this hypothesis, growth, physiology and general welfare of T. Iso and C. neogracile should be assessed in the presence of $A$. minutum. Second, cytotoxicity could affect scallop tissues directly, notably gills. Filtration rate, and thus food intake, could then be hindered. Negative effects of extracellular compounds upon tissues have been hypothesized to explain a stronger decrease of filtration rates in oysters $C$. gigas and clams Ruditapes philippinarum, as well as inhibition of the clearance rate in C. gigas, during exposure to the BEC strain (Contreras, 2011). Similarly, unknown extracellular polysaccharides have been suspected to affect the feeding activity and clearance rate of Mytilus edulis and Mercenaria mercenaria exposed to Aureococcus anophagefferens (Tracey, 1988; Bricelj \& Lonsdale, 1997 Bricelj et al., 2001). This direct contact with brown tide cells was firstly highlighted by Ward \& Targett (1989a, b). Feeding rate of scallops exposed to BEC in the present study could be affected in a similar way. Histological observations of the present study reinforced this hypothesis. Overall, melanisation in gills was higher in great scallops exposed to the BEC strain than for both other conditions. Further, there were significant effects of both, BEC and PST strains upon the mantle. Melanisation of the mantle and gills has been described in other scallop species exposed to A. catenella (Hégaret et al. 2012). This species of algae produces lytic compounds and can induce haemocyte infiltration and melanisation with direct contact with tissues (Basti et al. 2015). Histology revealed haemocyte infiltration higher in the BEC condition, with trends for mantle and digestive gland, and significantly, for muscle. All these observations could indicate direct tissue damage by the harmful alga.

\section{Escape behaviour}

The higher reaction time of scallops exposed to the BEC strain clearly indicated an effect of bioactive, extracellular compounds. The escape response of BEC-exposed scallops seemed to be less effective following contact with starfish. Chemosensitivity is involved in the escape response of scallops, and the behavioural reflex of escape is dependent upon tactile and chemical stimuli that are perceived by ciliated epithelial cells of the mantle, particularly on tentacles (Wilkens, 2006). Present results suggest that the recognition of a predator may be disrupted by direct tissue damage (such as melanisation) caused by bioactive, extracellular compounds from Alexandrium. The decrease in reaction time between the first and second challenge in all conditions suggested a faster recognition of predator after a first contact. The clapping time was also significantly higher in the BEC condition. At the beginning of the escape response, the striated adductor muscle allows for quick shell closures creating a jetpropulsion of water from the mantle cavity (Wilkens, 2006). But, during following swimming 
episodes, the smooth adductor muscle is used to gradually reopen the valves (Wilkens, 2006). So, an increase in clapping time, as observed here, might result from the response of the smooth adductor muscle to bioactive compounds, as suggested by the haemocyte infiltrations into the muscle of BEC-exposed scallops. Such haemocyte infiltrations in the adductor muscle have previously been observed in A. ventricosus exposed to Gymnodinium catenatum (Escobedo-Lozano et al. 2012), and this has been interpreted as a defence mechanism to evacuate bioactive extracellular compounds and limit the alteration of the muscle.

\section{Behavioral and physiological effects associated to exposure to PST}

Toxin accumulation in scallops exposed to the PST strain indicated that some toxic microalgae were ingested. Quantification of STX was performed in the digestive glands of scallops, the principal organ of PST accumulation (Estrada et al., 2010), where most alterations could also be observed. These alterations of digestive gland observed mainly in the PST condition could be linked to inflammatory responses (Habekorn et al., 2010a) of scallops responding to the presence of saxitoxin and its derivates. The saxitoxin and derivates could indeed cause damage in the digestive gland by being directly assimilated and biotransformed, or by being directly released in the digestive gland.

No effect of the PST strain exposure was observed upon scallop growth, but a significant effect upon escape response was found, potentially increasing scallop vulnerability to predators, as previously stated by Brokordt et al. (2013) with hypoxia. The number of claps and clapping time of scallops exposed to the PST strain were significantly lower in both challenges. Numerous studies have shown alteration of valve activity after exposure to toxic microalgae. Hence, A. catenella significantly degraded the escape response of Argopecten purpuratus (Hégaret et al. 2012), and A. monilatum reduced the valve gape in three shellfish species (M. mercenaria, C. virginica, P. viridis) (May et al., 2010). Moreover, swimming/clapping activity patterns were shorter during exposure to Protogonyaulax tamarensis (=syn. A. tamarense) (Shumway \& Cucci, 1987), and valve movements of the scallop N. subnodosus can be modified by exposure to PST producers (Estrada et al., 2010). Such modifications in valve activity might be attributable to the deleterious effects of PSTs upon the adductor muscle, as suggested by the correlation reported in C. gigas between the accumulation of PSTs in the digestive gland and the reduction in valve-opening amplitude (Mat et al., 2013), or the increase in the frequency of opening duration (Haberkorn et al., 2011). Results presented here showed myopathy of the adductor muscle in scallops exposed to both A. minutum strains, characterised by myoatrophy and hyaline degeneration of the muscle fibers. These results are consistent with observations in juvenile scallops $A$. 
purpuratus exposed to A. catenella (Hégaret et al., 2012), or in oysters C. gigas exposed to A. minutum (PST-producing strain) (Haberkorn et al. 2010a). Such myopathy could result from the direct effect of PSTs on muscle fibers, as hypothesized in C. gigas (Haberkorn et al. 2010a). Bricelj et al. (2005) showed that burrowing of Mya arenaria was not affected by exposure to non-PST-producing A. tamarense strain (CCMP115), but that incapacity to burrow was toxin-induced in clams and resulted from muscle paralysis (Bricelj et al., 1990; 2005). The link between the accumulation of PSTs and the paralysis of the adductor muscle has been observed in several bivalve species, such as C. gigas, M. edulis or A. ventricosus exposed to PST-producing dinoflagellates (Hégaret et al., 2007; Galimany et al., 2008; Escobedo-Lozano et al., 2012). Moreover, the injection of gonyautoxin (GTX, a saxitoxinlike toxin), produced by G. catenatum, into the muscle of the scallop N. subnodosus induced paralysis (Estrada et al., 2010). The paralytic effects of PSTs are caused by STX and derivatives, which block sodium channels (Bricelj et al., 2005) and can block nervous transmissions. The locomotory system depends upon the neuromuscular system: nervous information is sent through sodium channels to initiate movement by muscle contractions (Catterall, 1992). Thus, the decrease in the number of claps and clapping time observed in the present study is consistent with the action of STX upon scallop muscle by alteration of the neuro-muscular system, hindering the capacity of the muscle to contract and produce movement.

\section{Conclusion}

A Chaetoceros neogracile allelopathic assay clearly demonstrated the production of bioactive, extracellular compounds by both Alexandrium strains studied. This confirms that Alexandrium spp. can produce different types of toxic compounds, such as paralytic shellfish toxins, but also allelopathic compounds, which are not always related to each other.

Physiological and behavioural responses of scallops were clearly different between the two $A$. minutum strains. Scallops exposed to the "PST" strain, showed a decrease in the number of claps and clapping time. However, paralytic shellfish toxins did not seem to affect the recognition processes when exposed to starfish. Conversely, altered recognition processes could be observed in scallops exposed to the non-PST strain, which could be associated to the alteration of tissues responsible for this recognition. These alterations can be caused by the cytotoxic effects of BEC released by A. minutum, wich are also likely responsible for the reduction in filtration rate, thus causing cessation of growth by altering the tissues. 
These results clearly highlight the importance of working with different strains of Alexandrium sp. when assessing their possible interactions with other marine organisms, as a species producing high levels of PST may not be as toxic to other organisms as a strain producing a higher level of bioactive extracellular compounds. This study also demonstrates the importance to better characterize these extracellular bioactive compounds to better understand their interactions with sympatric organisms, such as phytoplankton species via allelopathy, but also other marine organisms via ichtyo- or cytotoxicity.

\section{Acknowledgments}

This project was supported by the National Research Agency ANR CESA, which funded the ACCUTOX project ANR-13-CESA-0019 (2013-2017) and Ifremer for internship gratification and experimental resources. The authors gratefully acknowledge all the colleagues who provided a valuable help during the experimentation, dissections and advices: Pierrick Le Souchu, Caroline Fabioux, Nelly Le Goïc, Anne-Laure Cassone, Christophe Lambert, Malwenn Lassudrie, Gaëlle Richard, Richard Guillonneau, Floriane Boullot, Anna Muir, Flavia Nunes, Ewan Harney, Arnaud Huvet, Philippe Soudant, Olivier Gauthier, Sébastien Hervé. We are also grateful to the staff of the Tinduff hatchery, in particular Florian Breton and Marie-Louise Muzellec for providing the biological material. Finally, the authors gratefully acknowledge Dr. Gary H. Wikfors for his very constructive comments and his English edits on the manuscript.

\section{References}

Anderson, D. M., Cembella, A. D., \& Hallegraeff, G. M., 2012. Progress in understanding harmful algal blooms: paradigm shifts and new technologies for research, monitoring, and management. Annu. Rev. Mar. Sci., 4, 143-176.

Antoine, L., 1978. La croissance journalière chez Pecten maximus (L.) (Pectinidae, Bivalvia). Haliotis, 9, 627-636.

Antoine, L., 1979. La croissance de la coquille Saint-Jacques Pecten maximus (L) et ses variations en mer Celtique et en Manche (Doctoral dissertation, Université de Bretagne Occidentale - Brest).

Arzul, G., Gentien, P., Bodennec, G., Toularastel, F., Youenou, A., \& Crassous, M. P., 1995. Comparison of toxic effects in Gymnodinium $c f$. nagasakiense polyunsaturated fatty 
acids, in : Lassus, P., Arzul, G., Erard, E., Gentien, P., Marcaillou, C., editors. Harmful Marine algal blooms. Techniques et documentation - Lavoisier, Intercept Ltd, Paris, 395400.

Arzul, G., Seguel, M., Guzman, L., \& Erard-Le Denn, E., 1999. Comparison of allelopathic properties in three toxic Alexandrium species. J. Exp. Mar. Biol. Ecol., 232, 285-295.

Baird, R. H., 1958. Measurement of condition in mussels and oysters. J. Cons., 23, 249-257.

Basti, L., Oda, T., Nagai, K., \& Nagai, S., 2015. Role of cytotoxicity and hemolysis in the deleterious effects of Alexandrium affine and A. catenella on early-life development of the japanese pearl oyster, Pinctada fucata martensii. J. Shellfish Res., 34, 608-608.

Bendif, E.M., Probert, I., Schroeder, D.C., Vargas, C., 2013. On the description of Tisochrysis lutea gen. nov. sp. nov. and Isochrysis nuda sp. nov. in the Isochrysidales and the transfer of Dicrateria to Prymnesiales (Haptophyta). J. Appl. Phycol. 25,1763-1776.

Bougrier, S., Lassus, P., Bardouil, M., Masselin, P., \& Truquet, P., 2003. Paralytic shellfish poison accumulation yields and feeding time activity in the Pacific oyster (Crassostrea gigas) and king scallop (Pecten maximus). Aquat. Living Res., 16, 347-352.

Brand, A. R., 2006. Scallop ecology: distributions and behavior,in: Shumway, S. E., \& Parsons, G. J., editors. Scallops: Biology, Ecology and Aquaculture. Developments in Aquaculture and Fisheries Science. Elsevier Sci. \& Technol., 35, 651-744.

Bricelj, V. M., Lee, J. H., Cembella, A. D., \& Anderson, D. M., 1990. Uptake kinetics of paralytic shellfish toxins from the dinoflagellate Alexandrium fundyense in the mussel Mytilus edulis. Mar. Ecol. Prog. Ser. 63,177-188.

Bricelj, V. M., \& Lonsdale, D. J., 1997. Aureococcus anophagefferens: Causes and ecological consequences of brown tides in US mid-Atlantic coastal waters. Limnol. Oceanogr., 42, 1023-1038.

Bricelj, V. M., \& Shumway, S. E., 1998. Paralytic shellfish toxins in bivalve molluscs: occurrence, transfer kinetics, and biotransformation. Rev. Fish. Sci., 6, 315-383.

Bricelj, V., MacQuarrie, S., \& Schaffner, R., 2001. Differential effects of Aureococcus anophagefferens isolates ("brown tide") in unialgal and mixed suspensions on bivalve feeding. Mar. Biol., 139, 605-616.

Bricelj, V. M., Connell, L., Konoki, K., MacQuarrie, S. P., Scheuer, T., Catterall, W. A., \& Trainer, V. L., 2005. Sodium channel mutation leading to saxitoxin resistance in clams increases risk of PSP. Nature, 434, 763-767. 
Brokordt, K. B., Fernández, M., \& Gaymer, C. F., 2006. Domestication reduces the capacity to escape from predators. J. Exp. Mar. Biol. Ecol., 329, 11-19.

Brokordt, K., Perez, H., Campos, F., 2013. Environmental hypoxia reduces the escape response capacity of juvenile and adult scallops Argopecten purpuratus. J. Shellfish Res. 32, 369-376.

Catterall, W. A., 1992. Cellular and molecular biology of voltage-gated sodium channels. Physiol. Rev., 72, 15-48.

Chateau-Degat, M. L., 2003. Les toxines marines : problèmes de santé en émergence. VertigO - Rev. Electronique Sci. Environ., 4.

Chauvaud, L., Thouzeau, G., \& Paulet, Y. M., 1998. Effects of environmental factors on the daily growth rate of Pecten maximus juveniles in the Bay of Brest (France). J. Exp. Mar. Biol. Ecol., 227, 83-111.

Chauvaud, L., Donval, A., Thouzeau, G., Paulet, Y. M., \& Nézan, E., 2001. Variations in food intake of Pecten maximus (L.) from the Bay of Brest (France): Influence of environmental factors and phytoplankton species composition. C. R. Acad. Sci. Ser. III, $324,743-755$.

Clark II,G.R., , 1974. Growth lines in invertebrate skeletons. Annu. Rev. Earth Planet. Sci., 2, 77-99.

Contreras, A., 2011. Effect of PSP-toxins producing dinoflagellates upon molluscan shellfish feeding behaviour: an assessment of the toxins role. Post-doctoral report - IfremerNantes.

Emura, A., Matsuyama, Y., \& Oda, T., 2004. Evidence for the production of a novel proteinaceous hemolytic exotoxin by dinoflagellate Alexandrium taylori. Harmful Algae, 3, 29-37.

Erard-Le-Denn, E., Morlaix, M., \& Dao, J.C., 1990. Effects of Gyrodinium cf. aureolum on Pecten maximus (post larvae, juveniles and adults), in: Graneli, E., Sudnström, B., Edler, L., Anderson, D.M., editors. Toxic Marine Phytoplankton. Elsevier: Amsterdam, 132136.

Ernst, W. R., Jonah, P., Doe, K., Julien, G., \& Hennigar, P., 1991. Toxicity to aquatic organisms of off-target deposition of endosulfan applied by aircraft. Environ. Toxicol. Chem., 10, 103-114. 
Estrada, N., Rodríguez-Jaramillo, C., Contreras, G., \& Ascencio, F., 2010. Effects of induced paralysis on haemocytes and tissues of the giant lions-paw scallop by paralyzing shellfish poison. Mar. Biol., 157, 1401-1415

Escobedo-Lozano, A. Y., Estrada, N., Ascencio, F., Contreras, G., \& Alonso-Rodriguez, R., 2012. Accumulation, biotransformation, histopathology and paralysis in the Pacific Calico Scallop Argopecten ventricosus by the paralyzing toxins of the Dinoflagellate Gymnodinium catenatum. Mar. Drugs, 10, 1044-1065.

Fabioux, C., Sulistiyani, Y., Haberkorn, H., Hégaret, H., Amzil, Z., \& Soudant, P., 2015. Exposure to toxic Alexandrium minutum activates the detoxifying and antioxidant systems in gills of the oyster Crassostrea gigas. Harmful Algae, 48, 55-62.

Flores, H. S., Wikfors, G. H., \& Dam, H. G., 2012. Reactive oxygen species are linked to the toxicity of the dinoflagellate Alexandrium spp. to protists. Aquat. Microb. Ecol., 66, 199209.

Ford, S. E., Bricelj, V. M., Lambert, C., \& Paillard, C. 2008. Deleterious effects of a nonPST bioactive compound (s) from Alexandrium tamarense on bivalve hemocytes. Mar. Biol., $154,241-253$.

Fulton, T. W., 1911. The Sovereignty of the Sea: An Historical Account of the Claims of England to the Dominion of the British Seas, and of the Evolution of the Territorial Waters, with Special Reference to the Rights of Fishing and the Naval Salute. The Lawbook Exch., L.td.

Gainey, L. F., \& Shumway, S. E., 1988. Physiological effects of Protogonyaulax tamarensis on cardiac activity in bivalve molluscs. Comp. Biochem. Physiol., 91C, 159-164.

Galimany, E., Sunila, I., Hégaret, H., Ramón, M., \& Wikfors, G. H., 2008. Experimental exposure of the blue mussel (Mytilus edulis, L.) to the toxic dinoflagellate Alexandrium fundyense: histopathology, immune responses, and recovery. Harmful Algae, 7, 702-711.

Gentien, P., \& Arzul, G., 1990. Exotoxin production by Gyrodinium cf. aureolum (Dinophyceae). J. Mar. Biol. Ass. U. K., 70, 571-581.

Gentien, P., 2006. Allelopathy in Karenia mikimotoi: a case study.12th International Conference on Harmful Algae, September 4-8, Copenhague, Denmark. .

Gentien, P., Lunven, M., Lazure, P., Youenou, A., \& Crassous, M. P., 2007. Motility and autotoxicity in Karenia mikimotoi (Dinophyceae). Phil. Trans. R. Soc. B: Biol. Sci., 362, 1937-1946. 
Guderley, H., Brokordt, K., Cortez H.M.P., Marty, Y., Kraffe, E., 2011. Diet and performance in the scallop, Argopecten purpuratus: force production during escape responses and mitochondrial oxidative capacities. Aquat. Living Res.24, 261-271

Guderley, H. E., Himmelman, J. H., Nadeau, M., Cortes, H. P., Tremblay, I., \& Janssoone, X., 2015. Effect of different predators on the escape response of Placopecten magellanicus. Mar. Biol., 162, 1407-1415.

Guillard, R.R.L. 1975. Culture of phytoplankton for feeding marine invertebrates animals. In: Smith, W.L., Chanle, Y.M.H. (Eds.), Culture of Marine Invertebrate Animals. Plenum Press, New York, USA, pp. 26-60.

Guillard, R.R.L., Ryther, J.H,.. 1962. Studies of marine planktonic diatoms. I. Cyclotella nana Hustedt and Detonula confervacea Cleve. Can. J. Microbiol. 8, 229-239.

Guillard, R. R. L., \& Hargraves, P. E., 1993. Stichochrysis immobilis is a diatom, not a chrysophyte. Phycology, 32, 234-236.

Haberkorn, H., Lambert, C., Le Goïc, N., Guéguen, M., Moal, J., Palacios, E., \& Soudant, P., 2010a. Effects of Alexandrium minutum exposure upon physiological and hematological variables of diploid and triploid oysters Crassostrea gigas. Aquat. Toxicol., 97, 96-108.

Haberkorn, H., Lambert, C., Le Goïc, N., Moal, J., Suquet, M., Guéguen, M., \& Soudant, P., 2010b. Effects of Alexandrium minutum exposure on nutrition-related processes and reproductive output in oysters Crassostrea gigas. Harmful Algae, 9, 427-439.

Haberkorn, H., Tran, D., Massabuau, J. C., Ciret, P., Savar, V., \& Soudant, P., 2011. Relationship between valve activity, microalgae concentration in the water and toxin accumulation in the digestive gland of the Pacific oyster Crassostrea gigas exposed to Alexandrium minutum. Mar. Poll. Bull., 62, 1191-1197.

Hégaret, H., Da Silva, P. M., Wikfors, G. H., Lambert, C., De Bettignies, T., Shumway, S. E., \& Soudant, P., 2007. Haemocyte responses of Manila clams, Ruditapes philippinarum, with varying parasite, Perkinsus olseni, severity to toxic-algal exposures. Aquat. Toxicol., 84, 469-479.

Hégaret, H., Brokordt, K. B., Gaymer, C. F., Lohrmann, K. B., García, C., \& Varela, D., 2012. Effects of the toxic dinoflagellate Alexandrium catenella on histopathogical and escape responses of the Northern scallop Argopecten purpuratus. Harmful Algae, 18, 7483. 
Howard, D. W., \& Smith, C. S., 1983. Histological techniques for marine bivalve mollusks. NOAA Tech. Memo. NMFS-F/NEC-25.

Krock, B., Tillmann, U., \& Cembella, A.,2006. Marine Biotoxins: Determination of Spirolide Profiles in Phytoplankton by LC/MS/MS. Invited lecture, LC-MS Tage, March 20, Oldenburg, Germany. hdl: 10013/epic.25303.d001.

Lambert, C., Lelong, A., Chambouvet, A., Le Goïc, N., Soudant, P., Hégaret, H., 2013. NonPSTs producing Alexandrium minutum have deleterious effects on Crassostrea gigas haemocytes or spermatozoa, in vitro, and allelopathic effects on Chaetoceros neogracile. Aquaculture., February 21-25, Nashville, Tennessee USA.

Landsberg, J. H., 2002. The effects of harmful algal blooms on aquatic organisms. Rev. Fish. Sci., 10, 113-390.

Lassus P., Abadie E., Amzil Z., Antoine E., Bardouil M., Baron R., Bornet B., Masselin P., Nezan E., Sechet V., Sibat M., Truquet P., Berard J. B., Gueguen M., Le Gall C., Ringelstein J., Fourgeaud E., Toledano N., Schmidt A., Defontaine A., Kermarrec L., Hegaret H., Soudant P., Barille L., Cognie B., 2006. Proliférations toxiques d'Alexandrium catenella dans l'étang de Thau: modèle de contamination des coquillagesRapport final. Réseau de Suivi Lagunaire du Languedoc-Roussillon : Bilan des résultats 2005. http://archimer.ifremer.fr/doc/00118/22927/.

Le Floc'h Pascal, Thébaud Olivier, Boncoeur Jean, Daurès Fabienne, Guyader Olivier, 2008. Une évaluation des performances économiques de la pêche côtière : le cas de la région Bretagne. Rev. Ecol. Reg. \& Urb., , 753-771. http://doi.org/10.3917/reru.085.0753.

Lelong, A., Haberkorn, H., Le Goïc, N., Hégaret, H., \& Soudant, P., 2011. A new insight into allelopathic effects of Alexandrium minutum on photosynthesis and respiration of the diatom Chaetoceros neogracile revealed by photosynthetic-performance analysis and flow cytometry. Microb. Ecol., 62, 919-930.

Li, S. C., Wang, W. X., \& Hsieh, D. P., 2002. Effects of toxic dinoflagellate Alexandrium tamarense on the energy budgets and growth of two marine bivalves. Mar. Environ. Res., $53,145-160$.

Lorrain, A., Paulet, Y. M., Chauvaud, L., Savoye, N., Nézan, E., \& Guérin, L., 2000. Growth anomalies in Pecten maximus from coastal waters (Bay of Brest, France): relationship with diatom blooms. J. Mar. Biol. Ass. UK, 80, 667-673. 
Lorrain, A., 2002. Utilisation de la coquille Saint-Jacques comme traceur environnemental : approches biologique et biogéochimique (Doctoral dissertation, Université de Bretagne occidentale - Brest).

Ma, H., Krock, B., Tillmann, U., \& Cembella, A., 2009. Preliminary characterization of extracellular allelochemicals of the toxic marine dinoflagellate Alexandrium tamarense using a Rhodomonas salina bioassay. Mar. Drugs, 7, 497-522.

Manfrin, C., De Moro, G., Torboli, V., Venier, P., Pallavicini, A., \& Gerdol, M., 2012. Physiological and molecular responses of bivalves to toxic dinoflagellates. Invertebr. Surviv. J., 9, 184-199.

Mat, A. M., Haberkorn, H., Bourdineaud, J. P., Massabuau, J. C., \& Tran, D., 2013. Genetic and genotoxic impacts in the oyster Crassostrea gigas exposed to the harmful alga Alexandrium minutum. Aquat. Toxicol., 140, 458-465.

May, S. P., Burkholder, J. M., Shumway, S. E., Hégaret, H., Wikfors, G. H., \& Frank, D., 2010. Effects of the toxic dinoflagellate Alexandrium monilatum on survival, grazing and behavioral response of three ecologically important bivalve molluscs. Harmful Algae, 9, 281-293.

Nielsen, M. V., \& Strømgren, T., 1991. Shell growth response of mussels (Mytilus edulis) exposed to toxic microalgae. Mar. Biol., 108, 263-267.

Ortiz, M., Jesse, S., Stotz, W., \& Wolff, M., 2003. Feeding behaviour of the asteroid Meyenaster gelatinosus in response to changes in abundance of the scallop Argopecten purpuratus in northern Chile. Arch. Hydrobiol., 157, 213-225.

Satake, M., Shoji, M., Oshima, Y., Naoki, H., Fujita, T., \& Yasumoto, T., 2002. Gymnocin-A, a cytotoxic polyether from the notorious red tide dinoflagellate, Gymnodinium mikimotoi. Tetrahedron Lett., 43, 5829-5832

Sellner, K. G., Doucette, G. J., \& Kirkpatrick, G. J., 2003. Harmful algal blooms: causes, impacts and detection. J. Industrial Microbiol. Biotechnol., 30, 383-406.

Shaw, B. L., \& Battle, H. I., 1957. The gross and microscopic anatomy of the digestive tract of the oyster Crassostrea virginica (Gmelin). Can. J. Zool., 35, 325-347.

Shumway, S. E., \& Cucci, T. L., 1987. The effects of the toxic dinoflagellate Protogonyaulax tamarensis on the feeding and behaviour of bivalve molluscs. Aquat. Toxicol., 10, 9-27.

Shumway, S. E., 1990. A review of the effects of algal blooms on shellfish and aquaculture. J. World Aquacult. Soc., 21, 65-104. 
Smolowitz, R., \& Shumway, S. E., 1997. Possible cytotoxic effects of the dinoflagellate, Gyrodinium aureolum, on juvenile bivalve molluscs. Aquacult. Int., 5, 291-300.

Tang, Y. Z., Kong, L., \& Holmes, M. J., 2007. Dinoflagellate Alexandrium leei (Dinophyceae) from Singapore coastal waters produces a water-soluble ichthyotoxin. Mar. Biol., 150, 541-549.

Thomas, G. E., \& Gruffydd, L. D., 1971. The types of escape reactions elicited in the scallop Pecten maximus by selected sea-star species. Mar. Biol., 10, 87-93.

Tillmann, U., John, U., 2002. Toxic effects of Alexandrium spp. on heterotrophic dinoflagellates: an allelochemical defence mechanism independent of PSP toxins. Mar. Ecol. Prog. Ser. 230, 47-58.

Tillmann, U., John, U., \& Cembella, A., 2007. On the allelochemical potency of the marine dinoflagellate Alexandrium ostenfeldii against heterotrophic and autotrophic protists. J. Plankton Res., 29, 527-543.

Tillmann, U., Alpermann, T., John, U. and Cembella, A., 2008. Allelochemical interactions and short-term effects of the dinoflagellate Alexandrium on selected photoautotrophic and heterotrophic protists. Harmful Algae, 7,52-64.

Tracey, G. A., 1988. Feeding reduction, reproductive failure, and mortality in Mytilus edulis during the 1985 "brown tide" in Narragansett Bay, Rhode Island. Mar. Ecol. Prog. Ser. , $50,73-81$.

Tran, D., Haberkorn, H., Soudant, P., Ciret, P., \& Massabuau, J.C., 2010. Behavioral responses of Crassostrea gigas exposed to the harmful algae Alexandrium minutum. Aquaculture, 298, 338-345.

Tran, D., Ciutat, A., Mat, A., Massabuau, J. C., Hégaret, H., Lambert, C., Le Goic N., \& Soudant, P., 2015. The toxic dinoflagellate Alexandrium minutum disrupts daily rhythmic activities at gene transcription, physiological and behavioral levels in the oyster Crassostrea gigas. Aquat. Toxicol., 158, 41-49.

Van Egmond, H. P., Aune, T., Lassus, P., Speijers, G. J. A., \& Waldock, M., 1993. Paralytic and diarrhoeic shellfish poisons: occurrence in Europe, toxicity, analysis and regulation. J. Nat. Toxins, 2, 41-83.

Villacorte, L. O., Ekowati, Y., Winters, H., Amy, G. L., Schippers, J. C., \& Kennedy, M. D., 2013. Characterisation of transparent exopolymer particles (TEP) produced during algal bloom: a membrane treatment perspective. Desal. Water Treat., 51, 1021-1033. 
Walne, P. R., 1970. Studies on the food value of nineteen genera of algae to juvenile bivalves of the genera Ostrea, Crassostrea, Mercenaria and Mytilus. Fish. Invest. Ser. 2, 26.

Ward, J. E., \& Targett, N. M., 1989a. Influence of marine microalgal metabolites on the feeding behavior of the blue mussel Mytilus edulis. Mar. Biol., 101, 313-321.

Ward, J. E., \& Targett, N. M., 1989b. Are metabolites from the brown tide alga, Aureococcus anophagefferens, deleterious to mussel feeding behavior ?, in: Cosper, E. M., Bricelj, V. M., and Carpenter, M. J., editors. Novel Phytoplankton Blooms. Pringer Verlag, NewYork, 543-556.

Wilkens, L.,A., 2006. Neurobiology and Behaviour of the Scallop, in: Shumway, S. E., \& Parsons, G. J., editors. Scallops: Biology, Ecology and Aquaculture. Developments in Aquaculture and Fisheries Science. Elsevier Sci. \& Technol., 35, 317-356.

Yamasaki, Y., Katsuo, D., Nakayasu, S., Salati, C., Duan, J., Zou, Y., Matsumaya, Y., Yamagushi, K., \& Oda, T., 2008. Purification and characterization of a novel high molecular weight exotoxin produced by red tide phytoplankton, Alexandrium tamarense. J. Biochem. Mol. Toxicol., 22, 405-415. 


\section{Figures}

Fig. 1: Experimental design of the experiment A: Juvenile scallops fed with a regular diet of C. neogracile and T-iso for 45 days of the acclimation phase, before being exposed for one week to the two A. minutum strains, one producing BEC (BEC condition), other producing PST (PST condition), and a control diet, similar as during acclimation phase (CON condition). Scallops were then fed with a regular diet of $C$. neogracile and T-iso for an extra two weeks (depuration phase). B: Forty (30 tagged and 10 non-tagged) scallops per condition were used for analyses: After the seven days of exposure, 5 scallops per condition were sampled for muscle condition index, 30 tagged scallops per condition were submitted to the escape response test, half of them were then sacrificed in order to perform histological measurements (on 15 individuals per condition), weight condition index (on the same 15 individuals per condition) and toxin analyses in the digestive glands (on 10 individuals per condition). The 20 sacrificed scallops per condition were analysed for shell growth rate. After the depuration phase, 5 scallops per condition were sampled for muscle condition index, and the 15 remaining tagged scallops per condition were submitted to the escape response test, before being sacrificed in order to perform analyses of weight condition index (on 15 individuals per condition) and toxin content in the digestive glands (on 10 scallops per condition).

Fig. 2: Light and epifluorescent pictures of fecal pellets of king scallops Pecten maximus containing intact A. minutum cells in scallops exposed to PST-A. minutum strain (PST) (A) or in scallops exposed to BEC A. minutum strain (BEC) (B)

Fig. 3: Escape response of $P$. maximus to predator; fed the control diet $(\mathrm{CON}), \mathrm{BEC} A$. minutum strain (CCMI1002) (BEC), or PST-A. minutum strain (AM89BM) (PST), in terms of reaction time $(A, B)$, number of claps $(C, D)$, clapping time $(E, F)$ and clapping rate $(G, H)$. (Kruskal-Wallis, P>0,05; median $+/$ - quantiles, cross $=$ mean. Letters a, b, c apply to significant differences between treatments for each challenge $(p<0.05)$. Fig. A, C, E, G: challenge 1; Fig. B, D, F, H: challenge 2. The second challenge (challenge 2) was performed 5 minutes after the first challenge (challenge 1), in order to test the repeatability of response.

Fig. 4: Histopathological observations in control scallops (A, C, E), in scallops exposed to BEC A. minutum strain (BEC) (B) and in scallops exposed to PST-A. minutum strain (PST) 
$(\mathrm{D}, \mathrm{F})$ on distinct tissues: mantle $(\mathrm{A}, \mathrm{B})$, adductor muscle $(\mathrm{C}, \mathrm{D})$ and digestive gland $(\mathrm{E}, \mathrm{F})$. M: Melanisation of mantle tissues in BEC scallops (B). H: Hyalinisation of muscle fibers in PST scallops (D). a: Digestive tubule alteration of PST scallops (F).

Fig. 5: Reconstituted growth curves of scallops fed the control diet (CON) (continuous line), scallops exposed to PST-A. minutum strain (PST) (dashed line) and scallops exposed to BEC A. minutum strain (BEC) (dotted line). Acclimation period with T-iso/C. neogracile, exposure period to A. minutum strains and recovery period with T-iso/C. neogracile are represented. A stop of growth is simulated for the BEC condition from 2 days of exposition. 
A

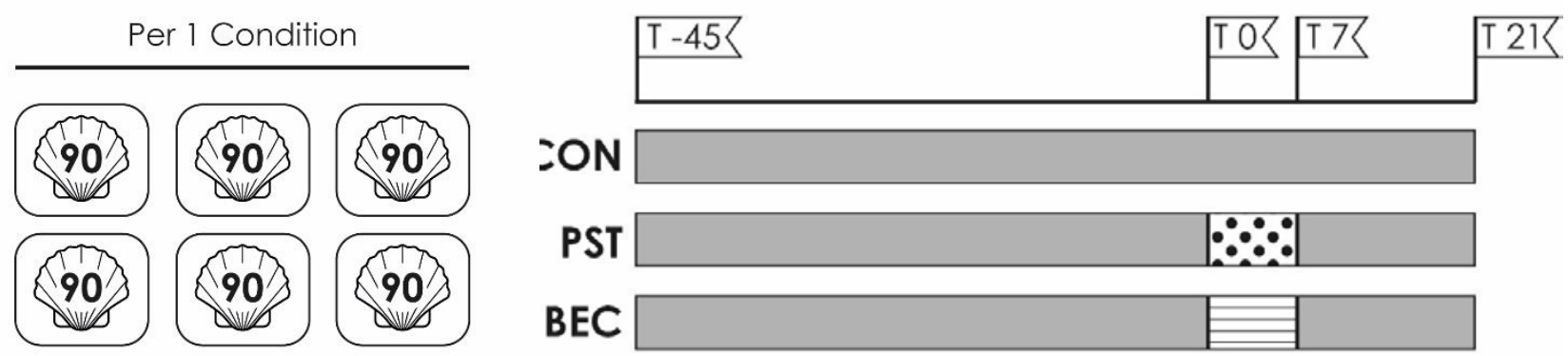

6 batches of 90 individuals

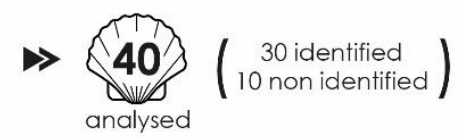

Acclimatation and recovery

Feeding with T-iso and C.neogracile

Exposure

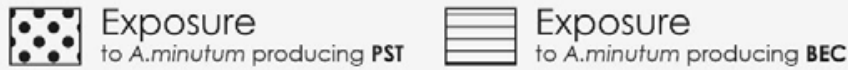

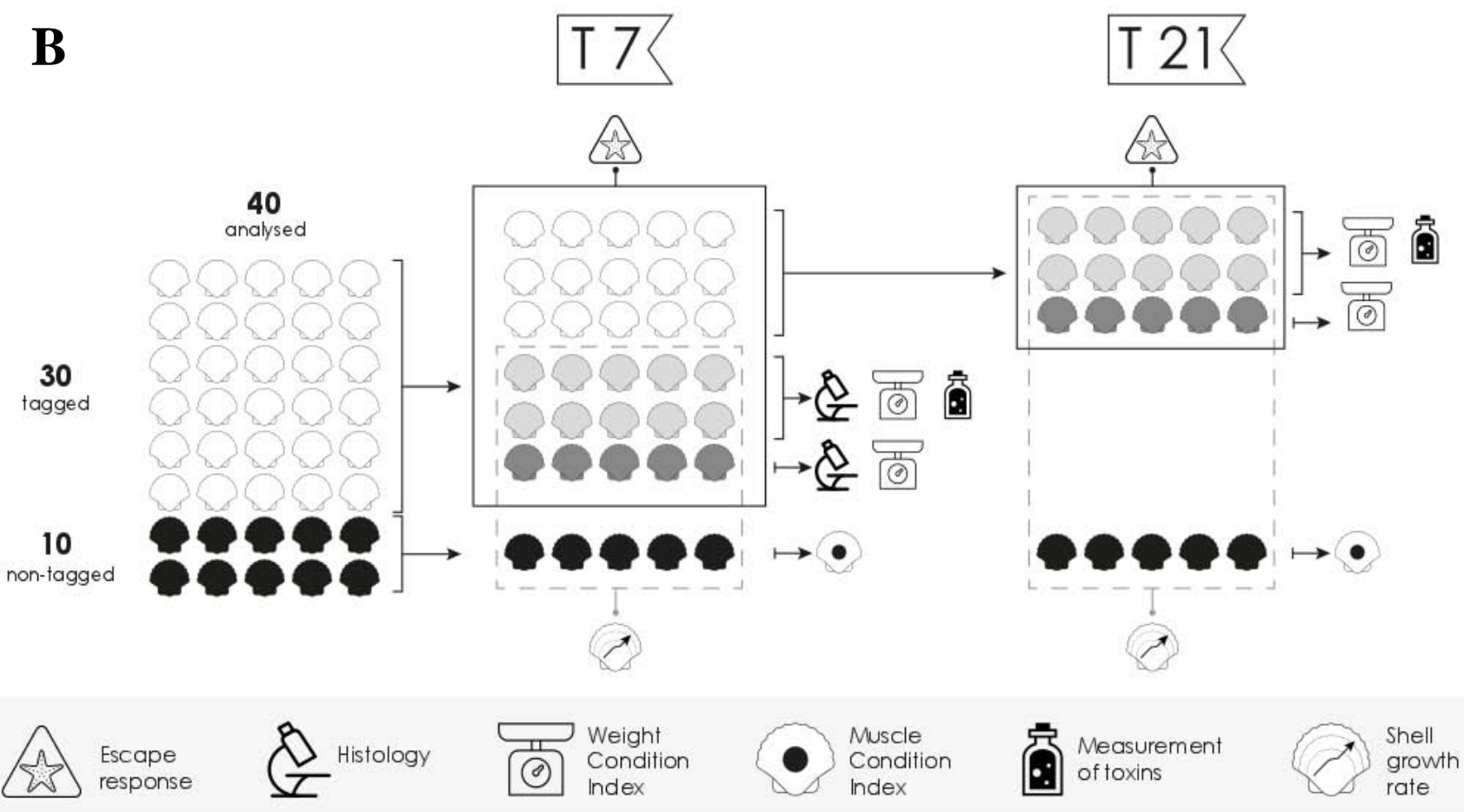



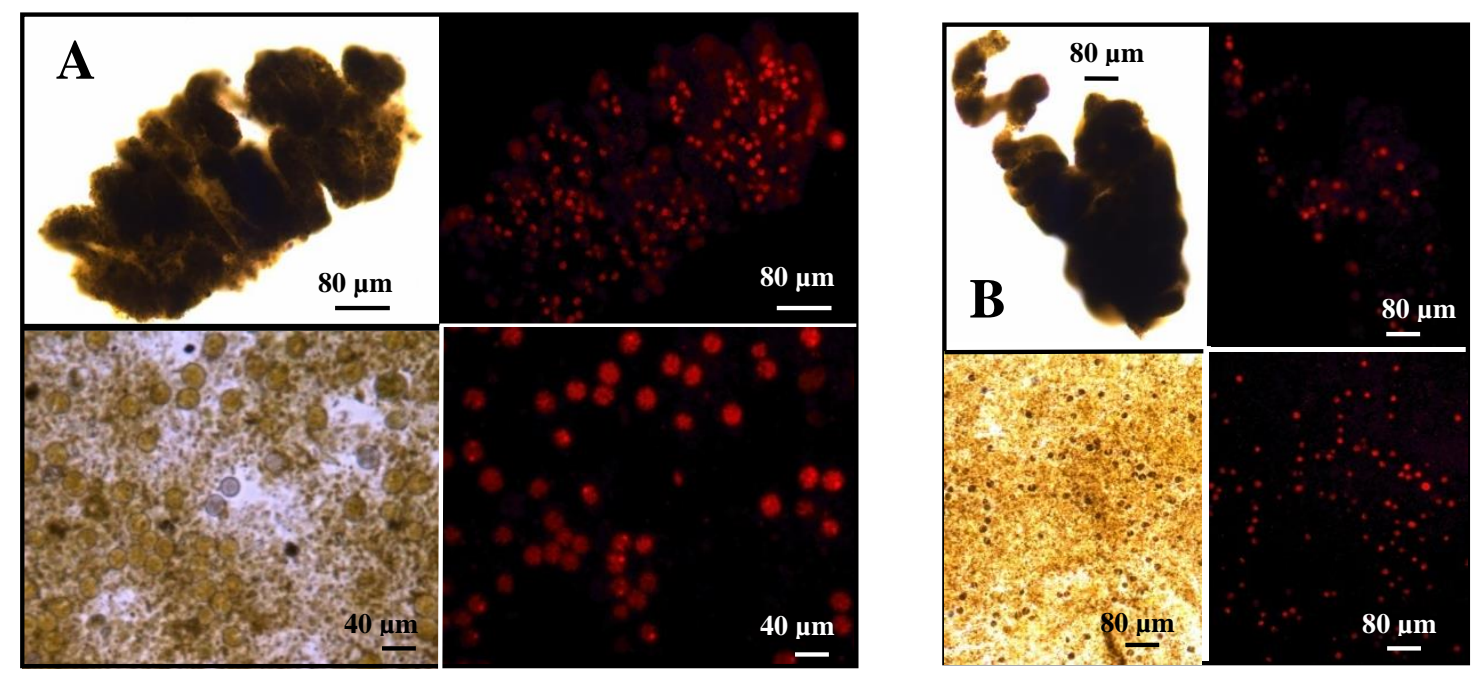

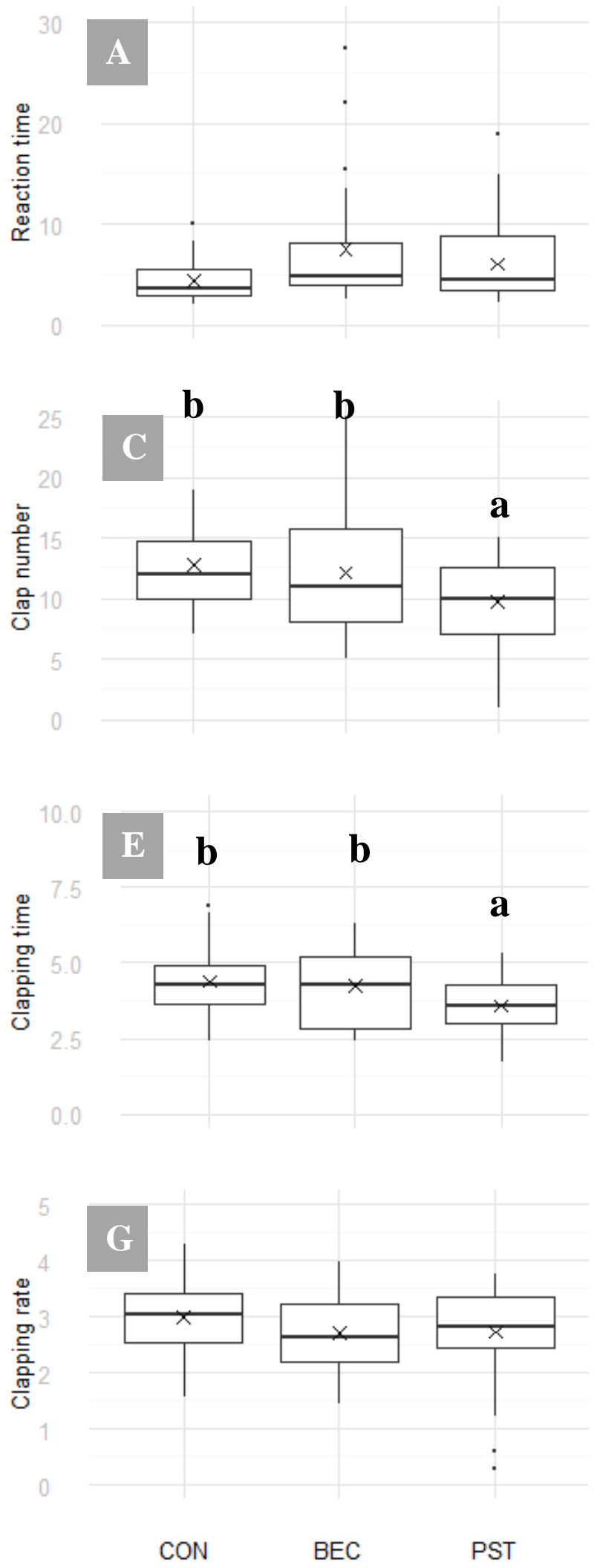

\section{B}
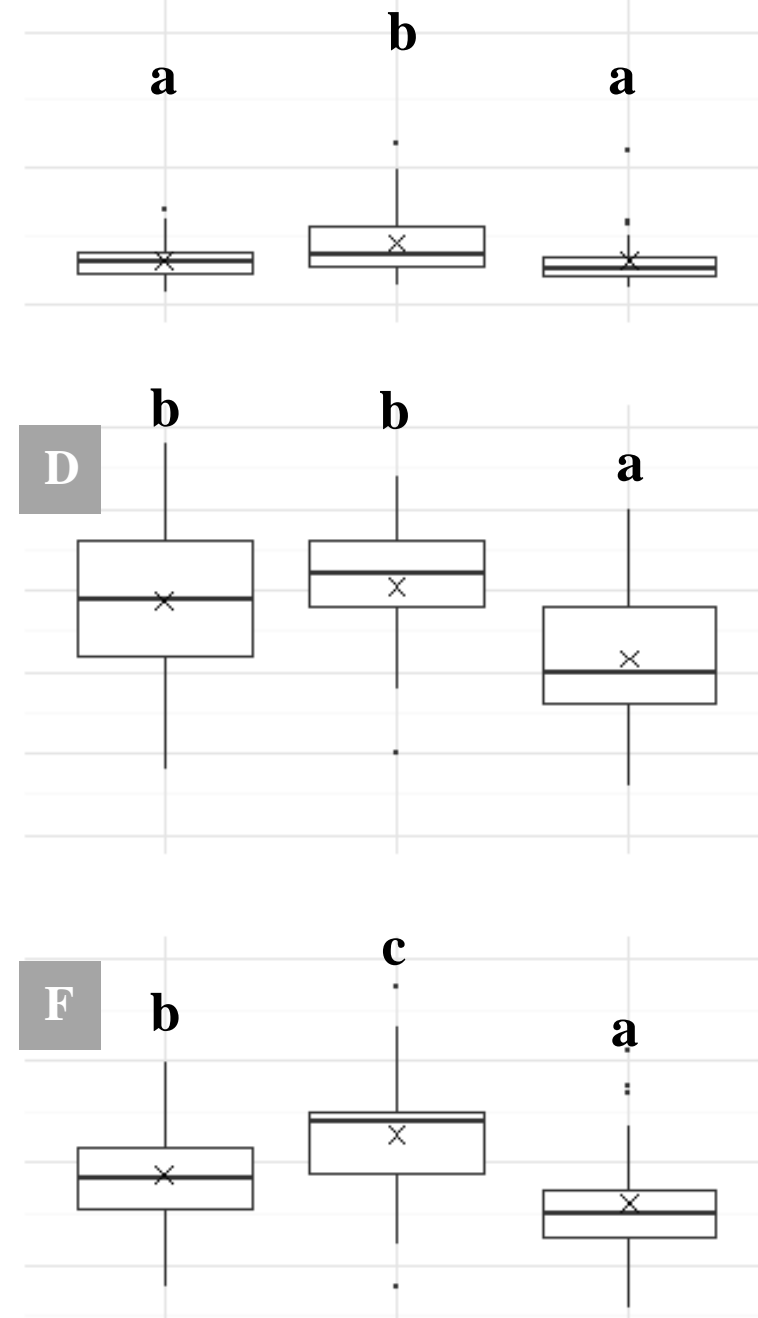

\section{II}

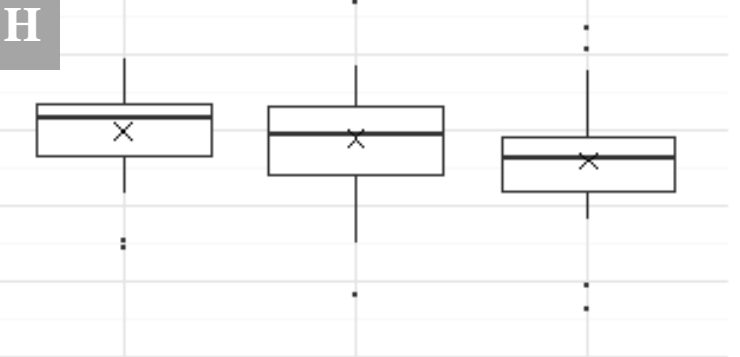

$\mathrm{CON}$

BEC

PST 


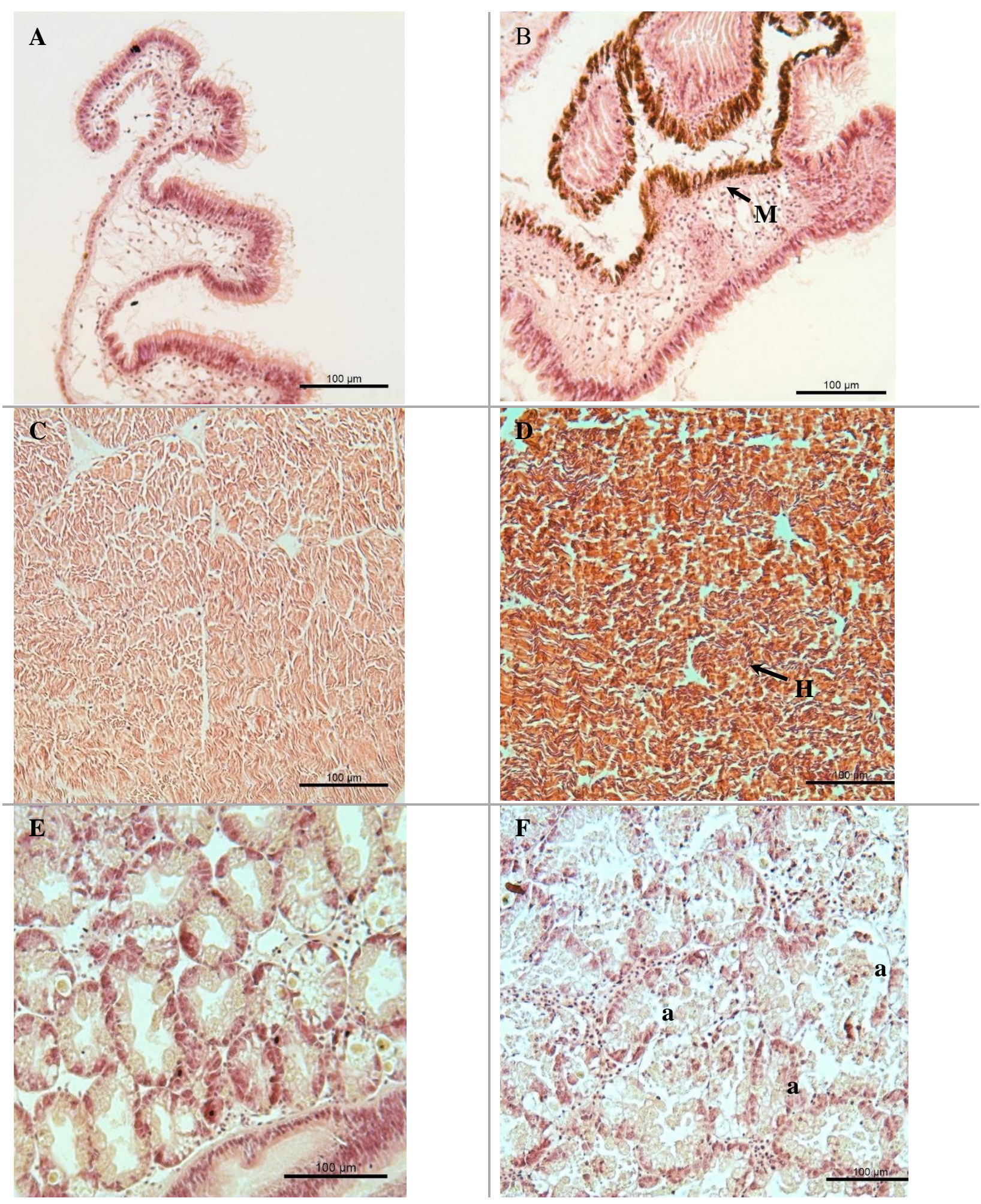




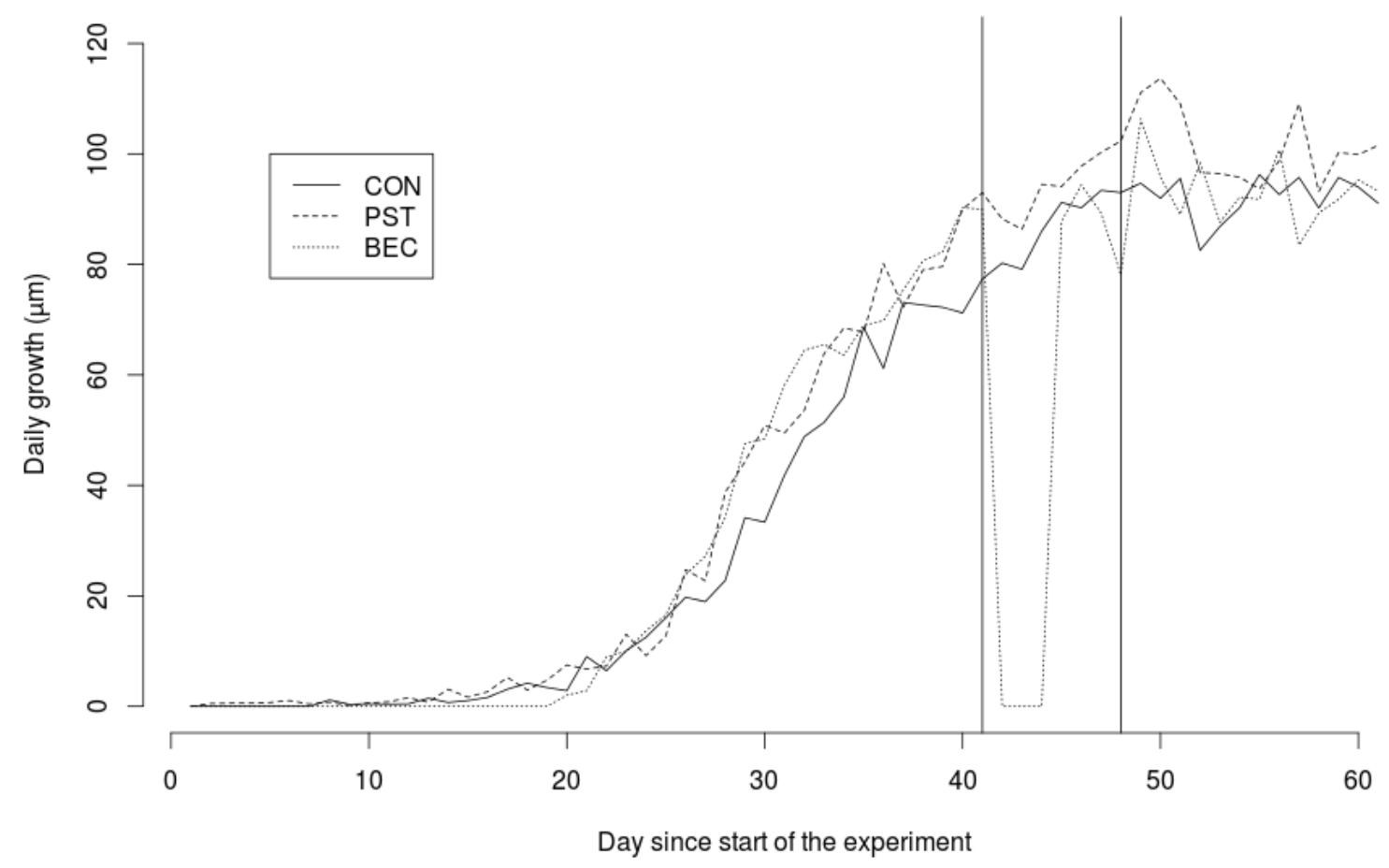


Table 1: Impact of supernatant of two strains of A. minutum (PST and BEC) or a L1-medium control on quantum yield and "FL3" chlorophyll fluorescence of the diatom C. neogracile $(\mathrm{n}=3$, ANOVA, Mean \pm SE, letters a,b,c apply to significant differences among treatments)

\begin{tabular}{l|l|l|l|l} 
& P-value & CON & BEC & PST \\
\hline Quantum Yield & $\mathrm{P}<0,01$ & $0,67 \pm 0,010$ (a) & $0,42 \pm 0,005$ (c) & $0,61 \pm 0,033$ (b) \\
FL3 & $\mathrm{P}<0,01$ & $319,0 \pm 9,88$ (a) & $214,1 \pm 3,56$ (c) & $280,6 \pm 6,56$ (b)
\end{tabular}


Table 2: Clearance rate $\left(\mathrm{L} \cdot \mathrm{h}^{-1} \cdot\right.$ ind $\left.^{-1}\right)$ of scallops $P$. maximus after three and five days of exposure the control diet (CON) or exposed to BEC A. minutum strain (CCMI1002) (BEC), or PST-A. minutum strain (AM89BM) (PST). (ANOVA, Mean \pm SE; letters a, b, c apply to significant differences among treatments).

\begin{tabular}{|c|c|c|c|c|}
\hline $\begin{array}{ll}\text { Days } & \text { of } \\
\text { exposure } & \end{array}$ & P-value & $\mathrm{CON}$ & BEC & PST \\
\hline Three days & $\mathrm{P}<0,05$ & $4,12 \pm 0,87$ (a) & $0,29 \pm 0,007$ (c) & $\begin{array}{l}2,03 \pm 0,1(b) \\
1,94 \pm 0,29\end{array}$ \\
\hline Five days & $\mathrm{P}<0,05$ & $3,67 \pm 0,17$ (a) & $1,01 \pm 0,1(b c)$ & (b) \\
\hline
\end{tabular}


Table 3: Impact of two strains of A. minutum (BEC and PST) on tissues of king scallops compare to control $(\mathrm{CON})$. Results are expressed as mean of stage intensity ${ }_{ \pm} \mathrm{SE}(\mathrm{n}=15$ per condition, Kruskal-wallis, *: $\mathrm{p}<0.05, \#: \mathrm{p}<0.10$; letters a, b, c apply to significant differences among treatments).

\begin{tabular}{ll|l|l|l|l} 
Tissues & $\begin{array}{l}\text { Histological } \\
\text { features }\end{array}$ & CON & BEC & PST & P-value \\
\hline \hline Gills & Melanisation & $0,86 \pm 0.18$ & $1,38 \pm 0.13$ & $0,97 \pm 0.17$ & NS \\
\hline \hline Mantle & Hemocyte infiltration & $2.07 \pm 0.16$ & $1.93 \pm 0.19$ & $2 \pm 0.19$ & NS \\
\hline & Melanisation & $0,73(\mathrm{a}) \pm 0.16$ & $1,46(\mathrm{~b}) \pm 0.19$ & $1,5(\mathrm{~b}) \pm 0.22$ & $*$ \\
\hline Muscle & Hemocyte infiltration & $1.21(\mathrm{a}) \pm 0.11$ & $2.17(\mathrm{~b}) \pm 0.22$ & $1.93(\mathrm{~b}) \pm 0.24$ & $*$ \\
\hline & $\begin{array}{l}\text { Hyalinisation of muscle } \\
\text { fibers }\end{array}$ & $0.68 \pm 0.12$ & $1.30 \pm 0.25$ & $1.13 \pm 0.26$ & $\mathrm{NS}$ \\
\hline & Atrophy & $0.59 \pm 0.19$ & $1 \pm 0.26$ & $1.33 \pm 0.31$ & $\mathrm{NS}$ \\
\hline & Hemocyte infiltration & $0(\mathrm{a})$ & $0.34(\mathrm{~b}) \pm 0.16$ & $0(\mathrm{a})$ & $*$ \\
\hline & $\begin{array}{l}\text { Hyalinisation } \\
\text { Atrophy + Hemocyte } \\
\text { infiltration }\end{array}$ & $1.18(\mathrm{a}) \pm 0.29$ & $2.65(\mathrm{~b}) \pm 0.41$ & $2.47(\mathrm{~b}) \pm 0.36$ & $*$ \\
\hline Digestive gland & Presence of brown cells & $1.5 \pm 0.15$ & $1.54 \pm 0.17$ & $1.5 \pm 0.17$ & $\mathrm{NS}$ \\
\hline & Hemocyte infiltration & $1.29 \pm 0.17$ & $1.36 \pm 012$ & $1.32 \pm 0.13$ & $\mathrm{NS}$ \\
\hline & Alterations & $0(\mathrm{a}) \pm 0$ & $0.27(\mathrm{a}) \pm 0.26$ & $1(\mathrm{~b}) \pm 0.20$ & $\#$ \\
\hline All tissues & $\begin{array}{l}\text { Mean of } \\
\text { melanisation }\end{array}$ & $1.58(\mathrm{a}) \pm 0.24$ & $3(\mathrm{~b}) \pm 0.25$ & $2,5(\mathrm{a}) \pm 0.30$ & $\#$ \\
\hline & $\begin{array}{l}\text { Mean of all hemocyte } \\
\text { infiltration }\end{array}$ & $4.5 \pm 0.25$ & $5.54 \pm 0.46$ & $5.31 \pm 0.45$ & $\mathrm{NS}$ \\
\hline $\begin{array}{l}\text { Mean of all histological } \\
\text { features }\end{array}$ & $6.8(\mathrm{a}) \pm 0.17$ & $9.14(\mathrm{~b}) \pm 0.70$ & $9.80(\mathrm{~b}) \pm 0.71$ & $\#$ \\
\hline
\end{tabular}

